\title{
KOMUNIKACINĖS KOMPETENCIJOS RAIŠKA PROFESINIO IDENTITETO PAIEŠKOJE
}

\author{
Nijolė Petronėlė Večkienė, Julija Eidukevičiūtė \\ Vytauto Didžiojo universitetas
}

\begin{abstract}
Anotacija
Straipsnyje siekiama pagrịsti komunikacinès kompetencijos aktualumą socialinio darbo profesinio tapsmo procese. Atsižvelgiama ị sąvokos socialinis sąsajas su ekonomikos, politikos kryptimis ir prioritetais, socialinio darbo pokyčiais praktikoje, pabrèžiant komunikaciją kaip veiklos bei patirtinio mokymosi galimybę ir šaltinį. Remiantis teorinès ir empirinès analizès rezultatais analizuojamas pagalbos šeimai procesas, akcentuojant galimybę plètoti komunikacinę kompetenciją individualios intervencijos procese ar grupeje. Straipsnyje laikomasi mokymosi paradigmos ir socialinio igalinimo metodologinių nuostatų, išryškinančių aktyvaus ir atsakingo veikejjo poziciją, bendradarbiavimo reikšmę, lemiančias profesinès veiklos sèkmę. Straipsnio pradžioje aptariamas dinamiškas ir nuolat kintantis socialinio darbo kontekstas, lemiantis tarpasmeninès komunikacijos trukdžius ir problemas, pagrindžiama komunikacinès kompetencijos plètotès būtinybè. Analizuojant mokymosi konstruoti igalinantị santykị su šeima teorines galimybes, aptariamas patirtinio mokymosi procesas, apibūdinama jo struktūra, dalyvių tarpusavio komunikacija, lemianti turinio konstravimą, naujų žinių kūrimą. Remiantis J. Eidukevičiūtès (2013) disertacinio tyrimo rezultatais, išryškinamos empirinès profesinio identiteto formavimosi prielaidos, atskleidusios ,pasilikimą“ pirminèje profesionalizacijos proceso fazèje. Aktualizuojant komunikacinès kompetencijos plètotę pagalbos šeimai procese, išryškinami esminiai profesionalizacijos nuostatų realizavimo trukdžiai, nulemti socialinių darbuotojų ir šeimos, kaip kliento, komunikacijos problemų. Atskleidžiama eksperto praktiko arba supervizoriaus palydejjimo būtinybė patirtinio mokymosi procese, formuluojama ižzalga, kad toks palydejimas igalina praktiką pasitelkus refleksiją plètoti savo, kaip socialinio darbuotojo, profesionalumą.

PAGRINDINIAI ŽODŽIAI: profesionalizacija, pagalbos procesas, šeima, komunikacinè kompetencija, patirtinis mokymasis, refleksija.
\end{abstract}

\begin{abstract}
The article aims to justify the relevance of communication competence in the process of professional development. There is taken into consideration the conection of concept "social" with trends and priorities of economy and politicy, changes in social work practice, emphasizing the communication as possibility and source for professional action and experiential learning. On the basis of theoretical and empirical results of analysis there is discussed the helping process for the risk family and the possibility to develop the communication competence in the process of individual intervention or group intervention. At the first part of article the learning paradigm and social empowerment methodological guidelines, which emphasize the the position of active and responsible character and the meaning of collaboration which determine the success of professional activity. There is discussed the context of the social work, which impact interpersonal communication obstacles and arising problems, the necessity to develop communicative competence is emphasized. Analyzing theoretical assumptions for learning in practice construction with aim to develop empowering relationship with family, there is discussed experiential learning process, definition of its structure, reciprocal communication, construction of practice content, the creation of new knowledges. The results of qualitative research (Eidukevičiūtè, 2013) revealed the problems of communication between social worker and family as a client. Social worker with sufficient practical activity experience usually remains in the primary phase of help process - contact establishment. In one case family proactiveness is expected but it remains "invisible". The research revealed the individual process of
\end{abstract}


experiential process the necessity of practitioner-expert or supervisor coaching in the experiential learning process by self-assessing and combining practical knowledge which were gained by acting in practice placement, theoretical knowledge and created professional knowledge. Such coaching enables to systematize elements recurring in situations, develop their professionality of social worker with the help of reflection.

KEY WORDS: professionalization, helping process, risk family, communicative competence, experiantal learning, reflextion.

\section{Ivadas}

Vienas esminių žinių visuomenès bruožų ir pagrindinis jos iššūkis - multidisciplininis šios visuomenès pobūdis, aktualizuojantis mokymąsi susikalbèti veikloje, kurioje dalyvauja skirtingi individai, įvairių subkultūrų atstovai (Brunevičiūtė ir kt., 2011). Tokioje visuomeneje žmogui kyla vis naujų reikalavimų, kurie lemia asmens ir aplinkos sąveikos kaitą, kintančius poreikius, ilgalaikes naujo tipo problemas (Večkienė, 2011). Kita vertus, žmogiškųjų išteklių ir kiekvieno žmogaus savarankiško gyvenimo galimybių išsaugojimas ir plètote tampa esminiu žinių visuomenès bruožu. Šioje kultūrinèje-socialinèje terpèje, kaip būtina, iškyla susikalbejjimo sąlyga. Tačiau objektyvi žinių visuomenès realybė - mokslų konvergencija, galinti sukelti paskirų veiklos sričių atstovų susikalbẻjimo sunkumus. Nepripažistant šios realybès, vargiai tikètinas skirtingų socialinès veiklos sričių, skirtingų profesijų atstovų, dirbančių vienoje organizacijoje, vienoje projekto komandoje susikalbėjimas (Brunevičiūtė ir kt., 2011). Ieškant galimybių susikalbẻti, bendradarbiavimo patirties plètotei būtina sukurti atitinkamas sąlygas. Tačiau pastarojo dešimtmečio mūsų tyrimai minètoje srityje išryškino nepakankamą socialinio darbo profesionalų komunikacinę kompetenciją, keliančią esminį bendradarbiavimo klausimą: ar galima ir kaip galima mokytis susikalbèti? (Brunevičiūtė ir kt., 2011; Eidukevičiūtè ir kt., 2005).

Socialinis darbas - tai empirinès prigimties veikla, ieškant savojo identiteto, tai kintanti profesija, nes socialinio darbo paskirtis yra socialinių problemų, kurias sukelia asmens, bendruomenès ir visuomenès tarpusavio sąveika, sprendimas. Socialinis darbuotojas, siekdamas optimizuoti kliento gyvenimo situaciją ir jo aplinką, kuri visada yra kompleksinè, ieško sprendimo galimybių, taiko ịvairių mokslų žinias. Teikdamas pagalbą šeimai socialinis darbuotojas susiduria su šeimos, kaip vieneto, kompleksiškumu, kiekvieno šeimos nario individualumu, unikalia patirtimi.

Straipsnio tikslas - remiantis teorinès ir empirinès analizės rezultatais aptarti pagalbos šeimai procesą ir galimybę plètoti komunikacinę kompetenciją individualios intervencijos procese ar grupejje, priimant žinių visuomenès keliamus 
iššūkius. Straipsnio problematiką galima apibūdinti remiantis P. Bourdieu (1990) teiginiu, kad žinių objektai yra konstruojami, ne užrašomi. Socialinis darbuotojas sąveikaudamas su klientu konstruoja savo profesinį elgesį, kalbą, laikyseną, taip plètodamas savajį veiklos pasaulio pažinimą. N. Večkienè (2010) pastebi, kad socialinių darbuotojų kompetencija praktiškai reiškiasi savitai: konkrečiai sąveikaujant su klientu jie savitai ịgyvendina vertybines nuostatas, ịgytas žinias, ịgūdžius. Siekiant suprasti profesinio žinių konstravimo procesą būtina atsižvelgti ị tai, kad habitus, pasak P. Bourdieu (1990), yra istorinis produktas, kuris lemia individualias ir kolektyvines praktikas, atitinkančias istoriškai generuotas schemas. Per veiksmą habitus užtikrina praktikos „taisyklingumą“ ir jos pastovumą, praeities patirčių aktualumą dabartyje. Konkreti praktika tampa labiau patikima, nei visos formalios taisyklès ar aiškiai išsakytos normos.

Šiame kontekste išryškejja tam tikras paradoksas. Pagalba šeimai buvo teikiama ir tarybiniais laikais. Tačiau tuo metu tèvai ir vaikai turejjo laikytis valstybės nustatytų krypčių, atitikti valstybės nustatytas normas ir, svarbiausia, ideologiją. Individualūs sprendimai, asmeninès vertybès nepageidauti, netgi negalimi. Šiuolaikinis požiūris ị šeimą ir jos atsakomybę iš esmès kitoks. Šeima suprantama kaip pirminė ir svarbiausia vaiko socialinè sistema, prisiimanti pagrindinę atsakomybę už jo/jos socialinę raidą. Todẻl socialinių darbuotojų ir šeimos santykis pagalbos procese turètų iš esmès skirtis. Tačiau pavojingu trukdžiu, kuriant igalinančios pagalbos santykị, formuojantis šiuolaikinị kontekstą atitinkančiam socialinio darbuotojo, socialinio pedagogo profesiniam identitetui, gali tapti nepakankamai reflektuojama istorinė patirtis, menkas kultūrinio konteksto pažinimas.

Straipsnyje laikomasi mokymosi paradigmos ir socialinio igalinimo metodologinių nuostatų, išryškinančių aktyvaus ir atsakingo veikejjo poziciją bei bendradarbiavimo reikšmę, lemiančias profesinès veiklos sėkmę. Straipsnị sudaro: ịvadas, 3 dalys ir išvados. Pirmoje dalyje aptariamas socialinio darbo kontekstas, lemiantis tarpasmeninès komunikacijos trukdžius ir tam tikras problemas, išryškinama komunikacinès kompetencijos plètros būtinybè. Antroje dalyje aptariamos teorinės mokymosi konstruoti igalinantị santykị su šeima galimybès, pabrěžiant patirtinio mokymosi procesą praktikoje ir jo dalyvių tarpusavio komunikaciją. Trečioje dalyje, remiantis disertacinio tyrimo rezultatais (Eidukevičiūtè, 2013), analizuojamos empirinès profesinio identiteto formavimosi prielaidos, aktualizuojant komunikacinès kompetencijos plètotę pagalbos šeimai procese.

\section{Komunikacinės kompetencijos aktualizavimas pokyčių kontekste}

Globalizacijos procesai lemia sparčius pokyčius įvairiose mūsų gyvenimo srityse. Pokyčius lydi nuolat kintantys ir didejjantys reikalavimai žmogui (Bell, 
2003), kurių dinamika lemia nuolatinę žinių plètrą ir kaitą, sukuria nuolatinio mokymosi prielaidas. Pokyčiai dažnai siejami su tokiais XXI amžiuje vartojamais visuomenès apibūdinimais: poindustrinè, postmodernistinè, paslaugų, vartojimo, žinių. Analizuojant literatūrą išryškèja esminè globalizacijos ypatybè: šiam reiškiniui apibūdinti būtinos trys dimensijos - politinè, socialinè, ekonominè. Laikantis tokio požiūrio straipsnyje pagrindžiamas komunikacinès kompetencijos plètotès aktualumas profesinio identiteto formavimosi procese. Akivaizdu, kad pagalbos žmogui samprata sukuria prielaidas skirtingų mokslo ir praktikos sričių specialistų bendradarbiavimui, atliepiant socialinio darbo kompleksiškumą pagalbos šeimai procese.

P. Bourdieu (1994) teigimu, egzistuoja dialektinè sąveika tarp lauko (objektyvių struktūrų) ir habitus (mentalinių, kognityvinių struktūrų, kurių dẻka individas veikia socialinèje erdvejje). Viena vertus, laukas nulemia habitus, kita vertus, būtent habitus suteikia laukui prasmę ir padaro jị vertingą. Habitus - tai aktyvus istorijos dalyvavimas mumyse. Jis generuoja mūsų praktikas, veiksmus, strategijas ir tai, kaip mes suvokiame pasauli. Habitus formavimuisi didelę reikšmę turi tai, kaip ir kur augome, gyvenome: mūsų socializacijos eiga, namuose vyravusios tvarkos, moralès normų, vertybių raiška. Reikšminga tai, kad habitus stengiasi pašalinti visas „ekstravagancijas“, t. y. elgesį, kuris nesuderinamas su objektyviomis sąlygomis (Bourdieu, 1990). Taigi habitus vienu metu yra ir praktikų kūrimo, ir jų supratimo bei vertinimo sistema. Abiem atvejais išryškejja lemiama socialinès situacijos, kurioje habitus formavosi, reikšmè. P. Bourdieu teigimu, kuo labiau socialinès struktūros atitinka tas, kuriose formavosi habitus, tuo mažiau žmogaus kasdienè veikla reikalauja specialaus svarstymo, ji paprasčiausia yra nesąmoninga. Autorius tai vadina praktikos logika. Lietuvos atveju sąlygos iš esmès pakitusios ir skiriasi nuo pradinių. Todèl socialiniam darbuotojui gali būti sunkiau apsispręsti ir veikti.

Yra ir dar vienas glaudžiai su nagrinèjama tema susijęs P. Bourdieu teorijos aspektas, teigiantis, kad ị lauka galima žiūrèti kaip ị struktūruotą pozicijų erdvę, kur pozicijos ir jų tarpusavio ryšiai yra nulemti skirtingos rūšies kapitalo paplitimo (Bourdieu, 1994). Individo pozicijos lauke priklauso nuo jo valdomo kapitalo dydžio ir disponuojamo kapitalo tipo (ekonominio, kultūrinio, socialinio, simbolinio) santykio. Ir čia galima ịžvelgti ryškių pokyčiu ir manyti, kad jie nevienodai paveikẻ skirtingą socialinių grupių, mūsų atveju - šeimos, gyvenimą. Keltina hipotezė, kad tarybinių laikų socialinė struktūra pripratino žmones laukti, kol kas nors jais pasirūpins, aktyvumas ir iniciatyva paprastai buvo nereikalingi ir net slopinami. Tačiau pasikeitusi situacija, ypač ekonomikos, šiuo metu reikalauja aktyvumo darbo rinkoje, verslumo, t. y. kitokios praktikos. 
Svarstant socialinio darbo profesinio identiteto klausimą svarbu įvertinti simbolinio kapitalo kaitą. Simbolinès vertybès, kuriomis buvo grindžiamas žmonių reikšmingumas ir prestižas pokyčių laikotarpiu, gerokai pakito. P. Bourdieu teorijas perkèlus ị Lietuvos socialinio gyvenimo praktiką, galima kalbẻti apie dar vieną bendradarbiavimo kliūčių ir tyrimų sriți: pokyčiai buvo tokie spartūs ir radikalūs, kad senasis habitus liko beveik nepakitęs, vis dar egzistuoja naujoje socialinejje erdvèje ir neleidžia išnaudoti objektyvių galimybių, esančių šioje socialinėje erdvėje. Habitus yra linkęs išsaugoti savo pastovumą ir ,gintis“ nuo pokyčių, atmetant tai, kas gali paneigti informaciją, suformavusią mūsų habitus.

Minèti psichosocialinio konteksto ypatumai leidžia teigti apie išsamios pokyčių analizès aktualumą Lietuvos socialinejje erdvejje, išryškinant pagalbos šeimai trukdžius ir galimybes. Tai patvirtina Vytauto Didžiojo universiteto Socialinio darbo katedros darbuotojų tyrimai ir studentų diplominiai darbai, kuriuose analizuojamas socialinio darbuotojo vaidmuo skirtingose pagalbos žmogui srityse. Šie darbai atskleidžia paradigminę kaitą išgyvenančio ir tik trečią dešimtmetị Lietuvoje pradejjusio socialinio darbo ịvaizdžio bei statuso problemiškumą.

Dažnai komunikacija apibrèžiama kaip paskirų individų, kurie remdamiesi asmenine patirtimi save identifikuoja kaip skirtingus nuo kitų, tarpasmeninė sąveika. Žmonès taiko skirtingas vertybių sistemas, tikèjimus, tam tikras normas, kurios konstruoja tam tikrą jiems būdingą realybę. Kiekvienas žmogus savyje turi tam tikrus jausmų, mąstymo, galimo veikimo ar neveikimo rèmus, scenarijus, kurie išmokstami per visą gyvenimą. Akivaizdu, kad nuo skirtumų suvokimo ir gebėjimo susikalbèti priklauso socialinès pagalbos organizavimas ir teikimas rizikos situacijoje esančiai šeimai.

Todèl komunikacijos sritis ypač svarbi analizuojant tarpasmeninę žmonių sąveiką individualios intervencijos procese ar dirbant su vaiku ir jo šeima. Norint būti kompetentingu šioje srityje reikia atkreipti dèmesị ị asmenybès pažinimą, komunikacinius ịgūdžius, psichosocialinị palaikymą, kultūros pažinimą. Nagrinèjant šią sritị detaliau, svarbu paminèti adaptavimosi prie naujos situacijos momentą, kuris gali sukelti kultūrinị šoką, lydimą baimès, streso, nepritarimo, svetimumo jausmų. Tai apima žmogaus nuostabą, juoką ar pasimetimą, kai girdi svetimą kalbą (Grebliauskienè, Večkienè, 2004). Kita vertus, tai yra socialinių profesijų atstovų kasdienybė, nes klientų ar besimokančiųų psichosocialinè situacija kinta kasdien. Profesionalui kiekvieną dieną tenka spręsti santykio užmezgimo, palaikymo ir puoselèjimo problemas.

Filologijos požiūriu, susikalbèti reiškia tarpusavyje susižinoti, susišnekèti, tai yra perduoti, pranešti žinią. Susikalbèti reiškia suvokti prasmę, esmę, išmanyti, sutikti, sutarti. Filologijos požiūris leidžia pažinti susikalbẻjimą, kaip objektą, at- 
skleidžiantị svarbų santykị tarp kalbos, mokymosi, žinojimo, naujų žinių kūrimo (Brunevičiūtè ir kt., 2011).

Komunikacijos mokslo požiūriu, susikalbèjimas - tai reikšmių kūrimas ir keitimasis jomis, kai žinia yra tam tikras objektas, ženklų konstrukcija (Brunevičiūtė ir kt., 2011). Tik abipusės abiejų šio proceso veikèjų pastangos lemia, kokia bendra reikšmė bus sukurta. Komunikacijos sėkmė priklauso nuo to, kaip siunčiamo pranešimo reikšmė atitinka gavèjo socialinę patirtị ar kultūrą, kiek pranešimo perdavimo / prièmimo procesas yra tikslingas. Edukologijos požiūriu, susikalbejjimas tai suderinta mokymo ir mokymosi veikla, kai veikiama toje pačioje paradigmoje, pagal tą patị ugdymo modeli. Tradiciškai suprantant, mokymo tikslas - informacijos perdavimas, o mokymosi tikslas - informacijos peremimas. Mokymosi paradigmos kontekste mokymosi, kaip informacijos prièmimo ir atkūrimo, samprata kinta ị interaktyvaus dinamiško ieškojimo proceso, kuriame tyrinèjant bei sąveikaujant su aplinka gimsta naujas supratimas, sampratą (Brunevičiūtè ir kt., 2011). Mokymosi procese žmonès plètoja žinias, ugdosi supratimą, gebejjimus, puoselèja vertybes, formuojasi požiūrius, kaupia patirti.

Minètos filologinès, komunikacinès ir edukacinès mokymosi susikalbèti prielaidos leidžia aktualizuoti komunikacinès kompetencijos plètotès profesinio identiteto formavimosi procese klausimą, kuris plačiau aptariamas antroje straipsnio dalyje.

\section{Patirtinio mokymosi ypatumai iggalinančio socialinio darbo praktikoje}

Šioje dalyje pristatomi patirtinio mokymosi ir profesionalizacijos raidos modeliai, akcentuojamas socialinio darbuotojo, kaip konsultanto, vaidmens reikšmingumas, detalizuojami kiekvieno profesionalizacijos etapo ypatumai, lemiantys tarpusavio komunikacijos ir pagalbos kokybę (Bernar, 2002; Dreyfus, Dreyfus, 1980). Literatūroje ir dokumentų tekstuose, kurie skirti socialinès veiklos teorijai bei praktikai, pabréžiami žmogiškieji ištekliai, lemiantys gamybinius, ekonominius rodiklius. Kita vertus, socialinis kapitalas gali padèti realizuoti žmogiškojo kapitalo potencialą. Bendruomenès, kurių aukštas socialinio kapitalo lygis, pasiekia geresnių rezultatų nei bendruomenès, kurios patiria socialinę fragmentaciją ir izoliaciją. Vyriausybès negali tiesiogiai padidinti socialinio kapitalo, bet gali sukurti palankią aplinką investuoti i jji. Pavyzdžiui, švietime ir tobulinimosi kursuose galima skirti daugiau dèmesio komunikacijos ịgūdžiams lavinti, jie labai svarbūs, skatinant tarpusavio pasitikèjimą ir ekonominį aktyvumą (Večkienė, 2010).

Komunikacinės kompetencijos svarbą patvirtina ir kintantis darbo pobūdis. Dèl ịvairių politinių, ekonominių, visuomeninių pokyčių Lietuvoje stebimas gyventojų populiacijos judejjimas iš pramonès ị paslaugų sriti, formuojasi naujas kliento ir 
gamintojo / paslaugos teikèjo santykis, keičiasi visuomenès vertybės. Tai patvirtina D. Bell (2003), analizuodamas industrinị ir poindustrinị darbą, gyvenimo bei veiklos šiose skirtingose visuomenėse ypatumus. Jis pabrěžia, kad prekes gaminančiose racionaliose visuomenèse asmuo ir jo vaidmuo atsiskiria, didejja individualizmas, susvetimejjimas. Kita vertus, dèmesys sutelkiamas į humanitarines, profesines ar technologines paslaugas, santykiai tarp individų nulemia veiklą. Šių prieštarų kontekste planuojant socialinių profesijų pokyčius svarbu nepamiršti, kad poindustrinès visuomenès ,socialinis vienetas yra ne individas, o bendruomenès organizacija“"(Bell, 2003, p. 223). Taip pabrèžiamas bendradarbiavimo ir savitarpiškumo prioritetas koordinavimo ir hierarchijos atžvilgiu. Taigi komunikacinių gebejjimų svarba tampa dar akivaizdesnè.

Profesionalų ir klientų bendradarbiavimas pagalbos žmogui procese skatina toleranciją ir dialogą, kuris įmanomas, jei laikomasi ịgalinimo nuostatos. Todèl išgyvenant socialinių profesijų kaitą esminè yra dvejopos mainų patirties refleksija: patirties, sukauptos bendradarbiaujant skirtingoms šalims ir skirtingoms socialinėms profesijoms (Lorenz, 1998). Šiuolaikinę igalinimo kompetenciją socialiniame darbe apibrèžiančių tekstų analizė leidžia teigti, kad kiekviena situacija, kurioje atsiduria profesionalas, gali būti specifiška. Be to, socialinès pagalbos proceso ypatumas - ne tik profesionalas patenka ị nuolat besikeičiančias sąlygas, būtina ir nuolatinè paslaugų gavėjo kaita. Taip išryškèja dvi tendencijos, kurios lemia socialinių profesijų ir pasirengimo joms pokyčius. Pirma, socialinè veikla orientuojasi i kliento aktyvumą, nes jis pats aktyviai dalyvauja problemos sprendimo procese. Antra, profesionalas dažnai veikia kaip įgalintojas (Pyne, 1996). Jis didina kliento motyvaciją, užtikrina tokị pagalbos procesą, kuris didina asmeninę, tarpasmeninę, siocioekonominę ir politinę galią, padeda pagerinti aplinkos sąlygas, pasiekti numatytą pokytị (Comton, Galaway, 1999). Šiame kontekste svarbu pabrēžti esminę socialinès veiklos nuostatą - paslaugos gavejjo situacija keičiasi tik kliento pastangų dèka.

Kadangi socialinio darbuotojo veikla daugiausia koncentruojasi $\mathfrak{i}$ asmens ir aplinkos sąveikos optimizavimą, kuris dèl kliento ir jo situacijos individualumo visada yra komplikuotas bei kompleksiškas, darbuotojas turètų veikti kaip komunikacijos organizatorius, padėdamas asmeniui atkurti ar sukurti ryšius, kurie leistu pasinaudoti aplinkoje esančiais ištekliais ar galimybėmis (Kavaliauskienė, 2005, Campton, Galaway, 1999). Minètame kliento ir aplinkos sąveikos optimizavimo procese dažniausia dalyvauja keli specialistai, turintys skirtingą profesinès veiklos patirtị ir skirtingą komunikacinę kompetenciją.

Praktikai ekspertai turètų padèti pradedantiesiems, dar besimokantiems socialiniams darbuotojams igyti praktinès patirties kartu veikdami konkrečioje organizacijoje. Žinojimas gali būti plètojamas, ịgytą patirtị reflektuojant bendrosios patir- 
ties ir teorinių bei praktinių žinių kontekste, keičiant turètus įsitikinimus, randant sąsajas tarp teorinių ir praktinių žinių (Večkienè, Eidukevičiūtè, 2009). Norẻdami igyvendinti savo siekius ir veikti profesionaliai socialiniai darbuotojai savo veikloje turètu gebèti taikyti refleksyvųji apmąstomaji socialinio darbo kompetencijos plètotès modelị. Šis modelis pabrèžia teorijos ir praktikos ryšio būtinumą, asmeninès ir profesinès patirties sąveiką, kuri svarbi socialinio darbuotojo profesinio tobulejjimo procese (Dirgelienè, 2008).

P. Burnard (2002) patirtinio mokymosi sampratos modelis (žr. 1 pav.) leidžia aiškiau suprasti mokymosi praktikos turinị, dalyvių vaidmenis ir bendradarbiavimo svarbą.

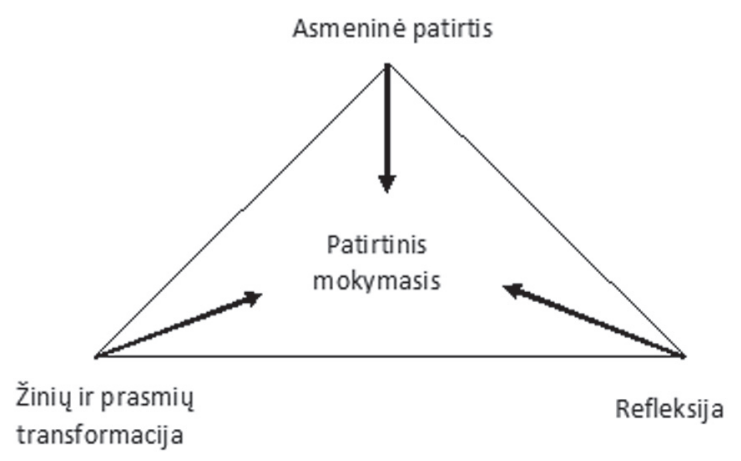

1 pav. Patirtinio mokymosi sampratos modelis (Burnard, 2002)

Fig. 1. Model for understanding of the experiantal learning (Burnard, 2002)

Pirmasis modelio elementas - asmeninè patirtis - reikšmingas dèl aktyvaus asmens ịsitraukimo ị mokymosi situaciją. Atliekant šią veiklą svarbus didesnę patirtị turinčio profesionalo palydejjimas. Praktinè veikla turètų ịtraukti visas besimokančiojo pažinimo galimybes: mąstymą, jausmus, elgesị ir net kūno pojūčius. Antrasis elementas - refleksija - svarbus ịgyvendinant mokymosi procesą. Kai kas nors ịvyksta, turime galimybę apsvarstyti buvusius ịvykius, tačiau kartais juos pastebime, bet nesvarstome, todèl neisimename. Refleksijos procesas, dalyvaujant konsultantui, padeda pažinti save kaip būsimą profesionalą, skatina susieti teorines ir praktines žinias. Trečiasis elementas - žinių ir prasmių transformacija, kuri nevyks, jei nebus refleksijos. Šia prasme reikšmingos grupès supervizijos, kuriose vedančiojo užduotis - sudaryti galimybes, kad grupès nariai, reflektuodami patirtį, galètų mokytis ir ịgyti žinių apie profesinị veikimą, kuris leistų plètoti profesinị identitetą. Kritiškas mąstymas, klausimų kèlimas, t. y. intrapersonalinè ir tarpasmeninè komunikacija, gebejjimai, reflektuojant grupejje, praplečia pažinimo lauką ir padeda svarstyti, tikrinti, analizuoti, vertinti. 
Taigi mokomasi veikiant. Jei mokymosi procese, tarpasmeninių santykių srityje, elgesys nesikeičia, neplètojama komunikacinè kompetencija, mokymasis nevertingas. P. Burnard (2002) teigia, kad praktinio mokymosi pagrindas - teorinių ir praktinių žinių integravimas. Pagrindiniai šio proceso bruožai: akcentuojamas veiksmas, žmogaus patirtis vertinama kaip mokymosi šaltinis, pabrěžiama asmens patirtis, besimokantieji skatinami reflektuoti savo patirti, aiškinamasis vaidmuo suteikiamas grupès vedančiajam / supervizoriui.

Gebèti iš atskirų, tarpusavyje nesusijusių kliento tikrovès fragmentų suformuoti darbinę problemą, pajausti profesijos galimybes bei ribas, veikti dažnai chaotiškoje ir fragmentiškoje situacijoje pradedančiam (ir ne tik) socialiniam darbuotojui gali būti pernelyg sudėtinga. Nors visada yra galimybė praktinèje situacijoje išbandyti, kas veikia, o kas - ne, tačiau šių bandymų objektas yra asmuo - organizacijos paslaugu gavejjas. Taigi eksperimentas atrodo neetiškas ir pavojingas. Todẻl patirtinio mokymosi procese labai svarbi yra besimokančiojo bei ji / ją lydinčių profesionalu (praktiko eksperto, dėstytojo, supervizoriaus) tarpasmeninè komunikacija. Taip sąveikaujant kuriamas mokymosi proceso turinys (Eidukevičiūtė, 2011).

Mokymosi procesas nèra statiškas, jis gali vykti kasdieninejje profesinejje veikloje, tačiau patyrimas ir igūdžiai ne iš karto iggyjami. S. Dreyfus, H. Dreyfus (1980), pirmieji pasiūlę penkių pakopų mintijimo raidos modelį, akcentuoja skirtingą keturių mintijimo operacijų (ịsiminimo, atpažinimo, sprendimo, suvokimo) raišką atitinkamuose profesionalumo plètotès proceso etapuose. Kiekviename nuosekliai igyvendinamame etape (naujokas - kompetentingas - igudęs - ekspertas, meistras) keičiasi profesionalo veikimas, jo gebejjimai įvertinti situaciją ir priimti sprendimus. Patirtinio mokymosi požiūriu reikšmingas S. Žorga (2006) keturių profesionalumo raidos etapų modelis, akcentuojantis socialinio darbuotojo konsultanto vaidmenị ir jo atlikimui būtiną komunikacinę kompetenciją. S. Žorga (2006) teigimu, pačioje veiklos pradžioje besimokančiajam būdingas iš pasyvaus stebinčiojo ir priimančio perèjimas ị aktyvų socialinio darbuotojo vaidmenį. Šis perėjimas besimokančiajam sukelia vaidmens ir veiklos netikrumą bei dvejones, jaučiamas nesaugumas, kritiškumas savo atliekamam vaidmeniui, išgyvenami netikrumo, bejëgiškumo, nekompetentingumo jausmai, dažniausia susitelkiama i konsultavimo technikas, bandymą tiesiogiai taikyti turimas teorines žinias.

Pirmajame (naujokas) etape labai svarbios instrukcijos (Dreyfus, Dreyfus, 1980), kurios padeda suvokti organizacijoje veikiančias taisykles, suteikiančias atliekamam veiksmui atitinkamas ribas. Taisyklès ir praktiko eksperto palydejjimas, skatinantis nuolat ịsivertinti, leidžia pradedančiam socialiniam darbuotojui mokytis ir tobulinti savo veiklą praktiškai. Šiame etape išgyvenami du lygiagrečiai vykstantys procesai: formuojasi profesijos identitetas ir mokomasi užmegzti dalykine komunikacija grindžiamą santykị su klientu, siekiant surasti problemų 
sprendimo būdą (Campton ir Galaway, 1999). Antrajame (kompetentingas) raidos etape pradedantieji vis labiau atpažįsta savo galimybes, trūkumus ir galimą santykio poveikị klientui (Žorga, 2006). Vis dar jaučiama įtampa ir netikrumas, tačiau jau bandoma rizikuoti, pasirinkti komunikacijos modelį, leidžiantị atskleisti save klientui, didejja tolerancija neapibrèžtoms konsultavimo situacijoms. Šiame etape gebama susikoncentruoti ị klientą, jo / jos gebejjimus ir poreikius, konstruoti dialogu grindžiamą tarpasmeninès komunikacijos procesą, prisiimti atsakomybę už jo vyksmą ir rezultatus, suvokiant konsultavimo svarbą.

Kompetencija igyjama tada, kai igyjama pakankama patirtis, leidžianti ịveikti konkrečias, realias praktines situacijas (Dreyfus, Dreyfus, 1980). Pradedantieji jau pastebi tam tikrus besikartojančius situacinius komponentus ir geba susieti juos su organizacijos kontekstu. Kol kas jie dar neturi tiek patirties, kad gebėtu ją apibendrinti iki abstrakčios sampratos. Todèl reikia praktiko eksperto palydèjimo, kuris padètų atpažinti ir pasirengti prasmingus veiklos elementus, grịstus asmenine bei profesine patirtimi, daugiau dẻmesio skiriant konsultavimo ịgūžių lavinimui, grịžtamojo ryšio užtikrinimui komunikacijos procese. Vienas iš nuolatini mokymąsi skatinančių būdų šiame etape yra ịgalinimas, t. y. pasitikèjimo savimi didinimas bei žinių, leidžiančių keisti savo profesinius veiksmus, plètotè. Siekiant savarankiškumo ir autonomiškumo būtina atsakomybė už savo veiksmų padarinius arba savimonè, galimybių paieška profesinès patirties plètotės procese turetų išlikti kaip besimokančiojo interesas (Grossman, 2007).

H. Dreyfus (1997) skiria kompetentingo darbuotojo, besimokančio iš savo patirties, mintijimo ir veikimo bruožus. Igijęs daugiau patirties darbuotojas žino daugiau praktinių situacijų, kurias geba susieti ir atpažinti tam tikrus besikartojančius elementus, tačiau sisteminti, formuluoti abstrakčias įžvalgas dar nepajègus. Naujoko palydèjimas patirtinio mokymosi procese tokiam darbuotojui gali būti dar viena atsakomybès reikalaujanti veikla. Vienas didžiausių iššūkių šioje situacijoje yra dialogo komunikacijos procese užtikrinimas, reikalaujantis pasitikejjimo savo profesionalumu ir pradedančiojo gebejjimu savarankiškai atlikti konkrečias veiklas.

S. Žorga (2006) teigia, kad trečiame (igudęs) profesionalumo raidos etape gerokai raiškesnè ilgalaikè motyvacija socialiniam darbui. Šiame etape socialinis darbuotojas geba prisiderinti prie kliento poreikių ir organizacijos reikalavimų, siekiant konsultavimo proceso rezultato. Profesionalas geba atrasti pusiausvyrą tarp mąstymo ir veikimo savo profesinėje veikloje, žino stipriąsias ir silpnąsias vietas, turi pageidaujamų klientų grupę. Darbuotojo profesinès teorinès ir praktinès žinios gilesnès, pasitikejjimas savo profesine ir komunikacine kompetencija didesnis.

Socialiniai darbuotojai, turintys pakankamai patirties atlikti ekspertizę, susidūrę su praktinėmis situacijomis nebesiekia atkurti daugialypės veiksmų sekos, pri- 
imdami sprendimus neatlieka kiekvieno veiksmo detalaus įvertinimo, bet pasinaudoja intuicija. Sprendimų prièmimas apima visą individualaus atvejo kontekstą, tačiau ekspertas patikrina ir gilinasi ị problemiškas, sudetingas situacijas, kai intuityviai veikti nepakanka. Tenka atsižvelgti ị neịprastas, rizikingas ir atsakomybės reikalaujančias situacijas arba savo veiksmus ir sprendimus reikia pagrịsti vadovui arba klientui. Socialinis darbuotojas ekspertas (ketvirtasis raidos etapas), pasak H. Dreyfus (1997), turi pakankamai patirties patarti, diagnozuoti ir vertinti, siūlyti sprendimus ir rekomendacijas realioms situacijoms. Profesinès veiklos meistriškumas (penktasis raidos etapas) leidžia plèsti socialinio darbuotojo eksperto kompetencijas, palydint mažiau patirties turintį kolegą. Šiuo atveju ypač reikšmingas yra eksperto gebėjimas plètoti dialogą su kolega, pripažinti besimokančiojo savarankiškumą pagalbos klientui teikimo procese, išlikti išorinio vertintojo pozicijoje.

Refleksija atlieka esminị vaidmeni praktinio mokymosi procese. Ji ịprasmina naują igytą patirti. J. Johns (2009) refleksiją apibūdina kaip atsargų, detalų ir realistišką žiūrẻjimą ị veidrodị, kuriame matomas pats veikiantis žmogus, jị supantys vaizdai, išgyventi ịspūdžiai tam tikros situacijos kontekste. Ilgainiui toks savęs stebejjimas profesionaliam socialiniam darbuotojui tampa gyvenimo ịgūdžiu, leidžiančiu išlikti atviram ir jautriam atsirandančioms galimybėms bei alternatyvoms. Gebejjimas reflektuoti ypač svarbus tada, kai praktikas susiduria su nauja keblia situacija, kurią bando išspręsti, ịveikti. Reflektuojant ị problemą ar situaciją bandoma pažvelgti iš naujo, kitaip, galimi nauji sprendimai, naujos ịžvalgos. Be to, labai svarbu, kad socialinio darbo profesionalas gebėtų reflektuoti ne tik atliekamą veiklą, bet ir apimtų visą profesinị ,žinojimą“, ịtraukdamas ir buvusią patirti. Taip retrospektyviai apibendrinama patirtis gali išlikti reikšminga ir ateityje. Refleksijos supratimas praplečiamas patirtinio mokymosi procese, kai reflektuojant ne tik bandoma susivokti veikloje, bet ir siekiama keisti savo profesinio elgesio modeli (Jarvis, Gibbson, 1997).

Siekiant atrasti individualius profesionalumo plètotès būdus, ieškant atsakymo i klausimą, kaip mokytis praktinèse situacijose, svarbs yra profesionalus supervizoriaus palydejjimas. Supervizijos svarba išryškejja, kai svarstoma profesionaliai intervencijai būtinų teorinių ir praktinių žinių integravimo būtinybė, kuriant naujoms situacijoms aktualias žinias. Esant netikètai ir visada netipinei kliento situacijai, patirtinio mokymosi procese ịgytos praktinès žinios reflektuojamos, konceptualizuojamos ir modifikuojamos. Tai vienas didžiausių iššūkių praktikos procese, reikalaujantis ,žinojimo apie tai“", kuris kuria ir numato alternatyvas ,žinoti kaip“ (Jarvis, 2001). Viena pagrindinių supervizoriaus užduočių - padėti susieti praktines žinias, igytas veikiant praktikos vietoje (žinojimas kaip), teorinių studijų metu igytas žinias, apimančias ịvairias mokslo disciplinas (žinojimas kodèl), ir integruojant abi šias epistemas susikurti profesines žinias (žinojima apie tai). Sistemin- 
damas, susiedamas tris skirtingas epistemas, atpažindamas jose besikartojančius elementus, pasitelkęs intrapersonalinę ir tarpasmeninę komunikaciją, socialinis darbuotojas tobulina savo profesionalumą.

Apibendrinant galima teigti, kad užtikrinus dialogu grindžiamą komunikaciją, organizacijoje galima sukurti tinkamas darbo ir mokymosi sąlygas, igalinančias darbuotojus plètoti profesinę kompetenciją. Tačiau, jei organizacijoje stebima menka bendradarbiavimą užtikrinančios komunikacijos raiška, jei dirbama mechaniškai, nereflektuojant, veikla socialiniams darbuotojams gali tapti statiška ar net blogėjanti, kelianti vidinius konfliktus, slopinanti motyvaciją mokytis, atnaujinti ir tobulinti savo veiklą.

\section{Santykis tarp socialinio darbuotojo ir kliento: Vaikų dienos centrų patirtis}

Trečioje straipsnio dalyje analizuojamos empirinès profesinio identiteto formavimosi prielaidos, aktualizuojant komunikacinès kompetencijos plètotę pagalbos šeimai procese. Šioje dalyje pristatomi disertacinio kokybinio tyrimo rezultatai (Eidukevičiūte, 2013). Tyrimas atliktas, vadovaujantis hermeneutine perspektyva. Tyrime dalyvavo 5 socialiniai darbuotojai, dirbantys nevyriausybinèse organizacijose, kurios teikia vaikų dienos centrų paslaugas.

Vaikų dienos centrai siekia suteikti tokias paslaugas, kurios ịgalintų šeimą užtikrinti vaiko gerovę, išvengti šeimos, kaip vieneto, išardymo ir vaikų perkèlimo ị globos sistemą. Pagrindinis socialinių darbuotojų veiklos tikslas - igalinti šeimą keistis. Todèl santykis su suaugusiu šeimos nariu tampa esminiu pagalbos teikejjo profesionalo uždaviniu. Gebejjimas užmegzti keičiantị santykị intervencijos procese - iššūkis socialinio darbuotojo profesionalumui. A. Kadushin (1979) santykio su klientu kūrimo procesą apibūdina vartodami „tilto“ metaforą. Taip pabrěžiama komunikacijos kanalų, kuriais informacija, žinia lengvai keliauja, pasiekdama abiejuose krantuose esančius asmenis, svarba. Kad žinios sẻkmingai „keliautų“, svarbios ir intervencijos metu patiriamos emocijos. Nuo santykio kokybės priklauso, ar bus užtikrintas aktyvus kliento ịsitraukimas (dialogas) pokalbio metu ir pokyčio įgyvendinimas santykiui pasibaigus. Saugumas, pasitikèjimas, patikimumas - esminiai reikalavimai intervencijos procese, kai klientas bando įveikti nerimą, ịtampą ir pavojų. Šie jausmai būdingi vaikų dienos centro klientu tapusios šeimos gyvenime.

Toliau tekste aptariamos temos, išryškejjusios analizuojant interviu tekstus, pateikiami interviu fragmentai, reikšmingi atskleidžiant dviejų tyrimo dalyvių sampratas. Abu tyrimo dalyviai - socialiniai darbuotojai, turintys pakankamą praktinès veiklos patirtị, dažniausiai išlieka pirminèje pagalbos proceso fazèje - kontakto 
užmezgimo situacijoje. Šiuo atveju tikimasi šeimos iniciatyvumo, bet tyrimo dalyvių pasisakymuose ji lieka tarsi „nematoma“. Komunikuojama dažniausia tik su motina, objektas - vaiko elgsena. Tyrimo dalyvis Leonas kalba apie mamą, kuri domisi vaiku, lankosi vaikų dienos centre, kad sužinotų, kaip vaikui sekasi. Tyrimo dalyvis, pristatydamas šeimos situaciją, neįvardija nè vienos savo profesinės veiklos. Mamos domèjimasis vaiko interesais atskleidžia pasiektą pasitikẻjimą ir profesini pripažinimą. Vaiko interesai yra komunikacijos tarp socialinio darbuotojo ir mamos objektas. İžengti ị privatų šeimos gyvenimą negalima, taigi socialinio darbuotojo pagalba suaugusiojo gyvenime tampa neịmanoma.

Leonas interviu ištraukoje [3.2.194] apibūdina socialinio darbuotojo ir kliento galimybes pradinėse intervencijos fazèse. Pirmasis kontaktas su tėvais atsiranda, vaikui pradējus lankyti dienos centrą. Tyrimo dalyvis pabrèžia, kad jam svarbu palaikyti bendradarbiavimo santykius su klientais. Tačiau, jo teigimu, tėvai turètų patys būti motyvuoti kalbètis su socialiniu darbuotoju. Profesinis santykis, kurị socialinis darbuotojas kuria su klientu, suprantamas kaip savaiminis. Pagrindinis Leono, kaip socialinio darbuotojo, tikslas - surinkti informaciją apie šeimą. Kalbėdamas apie socialines paslaugas tėvams vaikų dienos centre tyrimo dalyvis pirmiausia pabrėžia laiko, kurio reikia santykiui su klientu užmegzti, trūkumą. Leonas įsitikinęs, kad socialinio darbuotojo ir tėvų tarpusavio santykiui pirmiausia būtina, kad tèvai patys domètųsi dienos centru, siektų bendrauti su jame dirbančiais darbuotojais, kitų vaikų tėvais. Tyrimo dalyvio supratimu, tai užtrunka, tačiau reikia išlaukti, nes toks ,atsitraukimas“ sudaro pagrindą abipusiam pasitikèjimui. Kita vertus, belaukiant santykio užmezgimo, šeima nustoja lankytis vaikų dienos centre.

Vaikų dienos centro teikiamos paslaugos ir sąlygos, kurioms susidarius šeima tapo vaikų dienos centro klientu, Leonui neaiškios. Jo kalba apie kuriamą paslaugų gavejo ir teikejo santykị konkrečiais pavyzdžiais neiliustruojama, dažniau pateikiamos prielaidos. Tyrimo dalyvis teigia, kad socialinio darbuotojo ir kliento santykis tyrètų vystytis natūraliai, be priverstinio įsikišimo, todèl tikisi iš kliento veiksmų, kurie inicijuotu jo, kaip socialinio darbuotojo, veiksmus. Leonas teigia, kad abipusis pasitikejjimas priklauso nuo gerų aplinkinių atsiliepimų apie dienos centrą. Socialinio darbuotojo ir tèvų ryšys tyrimo dalyviui yra savaiminė vertybė, kuri dar ir labai trapi. Tikimasi, kad tèvai patys motyvuosis pokyčiui ir patys ieškos socialinio darbuotojo. Poreikio keistis pripažinimas traktuojamas kaip pagalbos procesas. Socialinio darbuotojo ir kliento komunikacija ị ši procesą neįtraukiama kaip pageidautina profesine veikla. Remiantis patirtinio mokymosi raidos modeliu, galima teigti, kad tyrimo dalyvio sampratos atskleidžia pirmajị - naujoko profesionalizacijos etapą. Tai patvirtina žemiau pateikiamos tyrimo dalyvio Leono interviu ištraukos. 


\subsubsection{7. bet bet ar ne per mažai paslaugu tèvams?}

3.2.188. ${ }^{0}$ labai geras klausimas. ${ }^{0}(.3)$ aš sakau vèlgi tam kad galètum su tévais vystyti tolesnị darbą visų prima reikia pagauti tą gera ryšị. (.) o tam reikia laiko. (2) $\downarrow^{0}$ tam reikia laiko. ${ }^{0}$ ir kartais to laiko neužtenka todèl kad, klientai keičiasi. (.) nu ta šeima tiesiog ne tai kad pabėga, bet jau pakeičia gyvenamą vietą ar ne, ir jos jau nebèra. viskas. 3.2.188.

3.2.189. ir tas tas užtrunka? (.) ir nepasitiki jumis?

3.2.190. iš pradžių taip. aš negaliu sakyt kad nepasitiki negaliu sakyt, kad pasitiki. ateina jie pirmiausiai taip, (.) na, (.) atsargiai truputèli išsiklausinėja. kas čia? kaip? (.2) jeigu būna iš anksčiau čia gyvenę ar ne, tarkim centro rajone. yra pažistami žmonès, ten tarkim kaimynai. gal ten kažką tu girdejjai apie tą dienos centrą, ar kažkas tai tokio. taip po truputèlị. kodèl tas dienos centras nori kad mūsų vaikai ateitų? kodèl jis nori kad mes lankytumèmès jame? nu toks lyg ir apžvalgomasis toks ir po truputėlị vyksta. a:a labai yra faina tarkim pabendrauti su tèvais per kažkokias tai šventes. nes tada susirenka daugiau tėvu, ir jie pabūna tokioj grupelèj, jie tarkim ir neformaliai pasišneka, tarkim be socialinio darbuotojo, ar tai atvykstant ar tai išvykstant. (.) va ir, nu po truputèlị užsimezga toki santykiai. (.) kartais ir tèveliai vyksta su mumis tarkim ị keliones. (.) nu kur nors netoli mes ten kažkur tai ar mieste, Kaune, vyksta. ar ne kaip aš minejjau ten gatvès piešimo akcijos. va:a ateina dar tevai ten. 3.2.190.

3.2.191. bet tai vyksta viskas po truputi, žingsnelis po žingsnelio?

3.2.192. taip. iš tikrujų tai jo, po truputeli žinokit. nes (.2) ta tokia staigi intervencija visu pirma tu taip staigiai ir ne nepamatysi visų problemu kurios, kurios yra toj šeimoj. tu gali matyt tas išorines. o vidinių, dèl ko ten tarkim (.) geria ar ne, dèl ko su tais vaikais blogi santykiai, arba ko tų pinigu nèra. hh tu matai kad taip yra, bet kodèl taip yra taip greit neišsiaiškinsi. (.) dèl to po truputèli viskas, taip žingsnis po žingsnio, ir galų gale jeigu staigią intervenciją kažkokią taikysi numatęs tik tai tą išorinę problemą. tai kaip jūs ir minèjot gali prarast tą šeimą dẻl staigios intervencijos. 3.2.192.

Tyrimo dalyve Justina, dirbanti socialine darbuotoja vaikų dienos centre, pasakojo apie organizacijoje veikiančią tėvų savitarpio pagalbos grupę. Išvengti profesinio ekspertavimo tėvų grupejje jai leido tai, kad ji neturi vaikų. Tai, jos nuomone, sukūrè palankias sąlygas, kurios paskatino tèvus dalintis patirtimi, o jai padejo „nebūti“ eksperte. Justina sukuria sąlygas tėvams išsakyti savo problemas, ieškoti sprendimo būdų. Sunkumų, kurie kyla šeimoje, pagrindas, jos teigimu, nėra tėvų motyvacijos trūkumas arba netinkama moralè, bet finansinių šaltinių, žinių, igū- 
džių, kurie padètų ịveikti situaciją, trūkumas. Justinai pavyksta susieti subjektyvias ir objektyvias šeimos sunkumų priežastis ir kurti pagalbos santykį.

2.1.213. suprantu. (.) ir tada kaip tu, (.) aš galvoju nu (.) kada tau yra pavyzdžiui sékmingas atvejis? (.) kada tu jautiesi kad nu<...>

2.1.214. iš tikrujų aš geriausiai tai aš skaitau kad tada kai bendradarbiauja tèvai. kai jie patys kažką tai stengiasi daryt ir jiem nu ta prasme ne tik tu vaiku rūpinies, bet ir jie kažką daro dèl vaiko ir dèl savęs. tai man tai yra nu didžiausias pasiekimas, kai jie eina ị kontaktą ir patys bendradarbiaut bando.] 2.1.214.

2.1.215. [po kiek laiko tas juyksta?

2.1.216. ne tai kad aš turiu jų ieškot. (.3) nu nežinau gal po kokių::ų su kuriuo gal kažkaip skirtingai, nes yra vieni kad jau po kelių mènesių:ų aiškiai matosi kad yra linkę i kontaktą. nu po kokių pusès metų tai jau matosi. (.) tie patys dabar kurie eina ị kontaktą. ${ }^{0}$ bet tai žinai yra tokių kurie visai neina ${ }^{0}$. ir pas mus dar yra ta grupelè kas dvi savaites tai kas pasilieka grupelèj irgi pasijaučia kad labai gerai jiem. 2.1.216.

2.1.217. koks tas tos tavo grupelès tikslas?

2.1.218. nu kaip ir savitarpio pagalbos žinai ten informacija maždaug pasidalint, bet iš esmès tai:i jie tarpusavyje pasidalina savo problemom ten savo ką jie žino, kąjie pasiekè kaip ten kokioj ịstaigoj kokie kokios plonybės kad ten kažką padaryti. bet iš esmès kaip aš sakau kad jie:e išsikalba vieni su kitais, nes vis tiek kai kalbasi daugiavaikè mama su daugiavaike tai jai jau nei ji kalbasi su manim kai aš neturiu vaikų žinai. nu vis tiek jai kažkaip kitaip turèjo. man tai kažkaip savitarpio pagalba ten labai, toks kvepia dalykas. (.) ir labai labai gerai pasijautè kad tie kurie eina ị grupelę pradejjo, labai su manim irgi su manim labai geri santykiai pasidarè. ${ }^{0}$ bet aišku yra tie kurie neina. ${ }^{0} 2.1 .218$.

2.1.219. kiek ju yra, kurie $n u<\ldots>$

2.1.220. tai eina tie kurie stengiasi kažką daryt. šeši penki žinai.

Tyrimo dalyvė išryškina tėvų savitarpio pagalbos grupès tikslą - įveikti vaikų apleistumą ir pagerinti savo, kaip tėvų, situaciją. Justina teigia, kad tėvai, kurie nori pakeisti savo situaciją, atranda galimybių puoselèti abipusius bendradarbiavimo santykius. Tyrimo dalyvė pabrèžia santykio svarbą ir, kaip ir daugelis šiame tyrime dalyvavusių socialinių darbuotojų, tai vadina „kontaktu“. Nors B. Campton ir B. Galaway (1999) kontaktą apibūdina kaip pradinị pagalbos proceso etapą, tyrimo dalyvė pabrèžia ir laiko svarbą socialinio darbuotojo bei kliento santykio raidai. 
Remiantis patirtinio mokymosi raidos modeliu, galima teigti, kad antruoju atveju tyrimo dalyvės sampratos atskleidžia ịgalinančio socialinio darbo su šeima, grindžiamo dialogo kultūra, prielaidas. Šiuo atveju šeima „matoma“ kaip aktyvus ir savarankiškas dialogo partneris pagalbos procese. Tačiau galima pastebèti pačios darbuotojos nepakankamą pasitikèjimą savo kompetencija. Tai leidžia teigti, kad tyrimo dalyvé reflektuoja savo patirtị. Jai aktualus praktiko eksperto arba supervizoriaus palydèjimas, kuris leistų pereiti $i$ antrajj - kompetentingumo etapą profesionalizacijos raidoje.

\section{Išvados}

1. Igalinimo nuostatos, grindžiamos tolerancija ir dialogu, akcentavimas pagalbos žmogui procese skatina numatyti tokias socialinès pagalbos strategijas, kurios leistų pletoti ne tik tiesioginès veiklos, bet ir bendradarbiavimo su klientu, kolegomis, vadovu patirties reflektavimą. Patirtinis mokymasis, grindžiamas refleksija ir praktiko eksperto ar supervizoriaus palydẻjimu, užtikrintų nuolatinį socialinių profesijų atstovų veiklos tobulinimą, eksperimentuojant, panaudojant naujas žinias apie vaiko ir jo šeimos, kaip kliento, situaciją, aktyviai dalyvaujant socialinio darbo, kaip profesijos kaitos, procese.

2. Empirinis tyrimas atskleidè du esminius profesionalizacijos nuostatu realizavimo trukdžius, kurie nulemti socialinių darbuotojų ir šeimos, kaip kliento, komunikacijos problemų:

- Socialiniai darbuotojai pagalbą teikianti santyki galèjo kurti tik su mama, išskirtiniais atvejais - su vaikų tèvu. Tyrimo metu išryškejjo pagalbos procese vyraujantis požiūris, kad moteris iš prigimties geba suteikti vaikams adekvačią ir pakankamą globą. Taigi socialiniam darbuotojui kuriant santykị su mama galima pasiekti pokyčiu šeimoje. Kiti šeimos nariai tarsi nedalyvauja šiame procese.

- Socialiniai darbuotojai, pasakodami klientų ir pagalbos jiems istorijas, intervenciją dažniausia apibūdindavo kaip konkrečių faktų apie šeimą rinkimą. Rečiau tyrimo dalyviai kalbẻdavo apie kuriamo santykio su klientu raidą, pokyčius šeimoje.

3. Apibendrinus straipsnyje pateiktos analizès rezultatus, išryškejja praktinių socialinio darbo žinių kūrimo problemiškumas, nepakankamai apmąstant savo veiklą, nepakankamai reflektuojant ir analizuojant individualaus patirtinio mokymosi procesą ir jo rezultatus; atsiskleidžia praktiko eksperto arba supervizoriaus palydèjimo būtinybė patirtinio mokymosi procese, isivertinant, susiejant praktines žinias, igytas veikiant praktikos vietoje, 
teorines žinias ir susikurtas profesines žinias. Toks palydejjimas ịgalina praktiką sisteminti situacijose besikartojančius elementus ir pasitelkus refleksiją plètoti savo, kaip socialinio darbuotojo, profesionalumą.

Gauta 20161002

Pasirašyta spaudai 20161203

\section{Literatūra}

Bell, D. (2003). Kapitalizmo kultūriniai prieštaravimai. Vilnius: Alma littera.

Bourdieu, P. (1994). Language and Symbolic Power. Cambridge: Oxford.

Brunevičiūtè, R., Večkienè, N. P. ir kt. (2011). Practical preconditions for the development of the interdisciplinary collaboration competence in healthcare. Santalka: filologija, edukologija, Nr. 19 (2), p. 132-140. Vilnius: Technika.

Burnard, P. (2002). Learning human skills - an experiential and reflective geode for nurses and health care professionals. Elsevier Science. Ltd.

Campton, B. R., Galaway, B. (1999). Social Work Process. Brooks / Cole Publishing Company.

Dirgeliené, I. (2008). Teorijos ir praktikos ryšio plètotė socialinio darbuotojo profesinèje veikloje. Acta Pedagogica Vinensia, Nr. 20, p. 90-101.

Dreyfus, H. L. (1997). Intuitive, Deliberative, and Calculative Models of Expert Performance. In C. E. Zsambok, G. A. Klein (eds.). Naturalistic Decision Making. Lawrence Erlbaum Associates.

Dreyfus, S. E., Dreyfus, H. L. (1980). A Five Stage Model of Mental Activities Involved in Direct Skill Acquisition. University of California: Berkley.

Grossman, S. C. (2007). Mentoring in nursing - a dynamic and collaborative process. Springer Publishing Company Ltd.

Grèbliauskienė, B., Večkienė, N. (2004). Komunikacinė kompetencija. Komunikabilumo ugdymas. Vilnius: Žara, $200 \mathrm{p}$.

Eidukevičiūtė, J., Kiznytė, N. (2009). Studentų adaptacijos kompleksiškumas organizacijoje praktikos proceso kontekste. Socialinis darbas. Patirtis ir metodai, Nr. 3(1), p. 91-104.

Eidukevičiūtė, J., Večkienè, N. (2009). Tutoriaus ir mentoriaus funkcijos socialinio darbo studentų mokomosios praktikos procese. Profesinis rengimas. Tyrimai ir realijos, Nr. 17, p. 204-231.

Eidukevičiūtė, J. (2009). Mokomosios socialinio darbo praktikos turinio sistemiškumo prielaidos. Socialinis darbas. Patirtis ir metodai, Nr. 8(2), p. 149-162.

Eidukevičiūtè, J. (2013). Family Social Work Practices in the Context of Transitional Lithuanian Society. Acta Universitatis Lapponiensis. Lapin yliopistokustannus: Rovaniemi.

Jarvis, P. (2001) Mokymosi paradoksai. VDU.

Jarvis, P., Gibosn, S. (1997). The Teacher Practioner and Mentor in Nursing. Midwifery, Health Visiting, and Social Services. Nelson Thornes.

Johns, J. (2009). Becoming a Reflective Practitioner. Wiley-Blackwell Publishing.

Kadushin, A. (1976). Supervision in Social Work. New York: Columbia University Press.

Kavaliauskiené, V. (2005). Socialinio darbo, kaip pagalbos žmogui profesijos, raidos aspektai. Acta Pedagogica Vinensia, Nr. 15, p. 230-239.

Lorenz, W. (1998). Social Professions for a Social Europe. European Dimensions in Training and practice of Social Professions. Ostrava: University of Ostrava.

Payne, M. (1996). What is profesional social work? Vebture Press.

Večkienė, N. P., Povilaikaite, S. (2005). Socialinio darbo sampratos kaita. Profesinis rengimas: tyrimai ir realijos, Nr. 9, p. 130-138.

Večkienė, N. P. (2010). Supervizija socialiniame darbe: paramą teikiantis bendradarbiavimas. Socialinis darbas. Patirtis ir metodai, Nr. 6(2), p. 119-134.

Večkienè, N. P. (2011). Bendradarbiavimu grindžiama socialinė partnerystė: studentų praktikos organizavimo teorinès prielaidos. Socialinis darbas. Patirtis ir metodai, Nr. 8(2), p. 113-134.

Žorga, S. (2006). Competences of a supervisor. Ljetopis socijalnog rada, Vol. 14 (2), p. 433-441. 
Nijolè Petronėlė Večkienė, Julija Eidukevičiūtè

\section{COMMUNICATION COMPETENCE IN SEARCHING FOR PROFESSIONAL IDENTITY}

\section{Nijolė Petronẻlė Večkienė, Julija Eidukevičiūtė}

\section{Summary}

One of the essential characteristics of knowledge society and its main challenge is the multidisciplinary nature of such society as this actualizes the learning to communicate in action with different individuals and members of different subcultures (Brunevičiūtè et al., 2011). In such society the new requirements are raised for the person and they impact the change of interaction between the person and environemnt, the changing demands, and lasting new type problems. On the other hand the preservation and development of human resources and opportunities of individual person independent living becomes the main characteristic of knowledge society. In this cultural-social environment as a must the condition of ability to understand arises. But objective reality of knowledge society - convergence of sciences may cause difficulties in communication between representatives of different science fields. By denying such reality, the individuals depending to different social activity fields with different professions working in one organization, in one project team can hardly communicate. (Večkienè, 2011). In search for the communication potential there is necessity to create conditions for collaboration experience development. The research of the current decade in the mentioned field highlighted essential collaboration problem: is it possible and how it is possible to learn to communicate? (Brunevičiūtè, Večkienè, 2011; Eidukevičiūtè, Večkienė, 2005).

Social work is activity of empirical nature, which is still in search of its own identity, a changing profession. The purpose of the social work is to solve issues, arising due to interaction between individual, community and society. Social worker in order to optimize the client's life situation and his/her environment which is always complex, is searching for solution possibilities and applies knowledge of various sciences. When providing help for the family, the social worker encounters the complexity of the family as a unit, the individuality of each member of the family and unique experience.

The aim of the paper is to dicuss the helping process for the risk family and the possibility to develop the communication competence in the process of individual intervention or group intervention, responding the knowledge society challenges. The problems analyzed in the paper can be described by using Bourdieu (1990) statement the knowledge objects are designed and not written. The social worker while interacting with the client is constructing his/her professional behaviour, 
language, understanding, thus developing the cognition of his/her activity world. Večkienè (2010) notice that the competence of social workers in practice is expressed in unique way: in particular interaction with the client they uniquely realize the attitude about values, gained knowledge and skills. In order to understand the professional knowledge construction process it is necessary to consider that $h a$ bitus, according to Bourdieu (1990), is historical product which impacts indivual and collective practices corresponding to schemes generated in history. Through the activity habitus ensure the "regularity" of the practice and its stability, the actuality of the past experiences to the present. The particular practice becomes more reliable than all the formal rules or clearly described norms.

In this context the specific paradox shows up. The help for family has been provided during the soviet times. But during these times the parents and children had to keep the directions regulated by state, correspond to norms regulated by state and the ideology was the most important. The individual solution, personal values were not desired and even impossible. The modern attitude to family and its responsibilities are radically different. The family is understood as primary and the most import social system for the child, which takes the main responsibility for his/her social development. Therefore the relationship between the social workers and the family in the process of help should be essentially different. But while creating the enabling help relation with developing professional identity of social worker, social educator (they should be responding to modern context) the insufficiently reflected historical experience, poor cognition of cultural context might become a dangerous obstacle.

The paper follows the learning paradigm and social empowerment methodological guidelines, which emphasize the position of active and responsible character and the meaning of collaboration which determine the success of professional activity. The paper consists of introduction, 3 parts and conclusions. The first part discuss the context of the social work, which impact interpersonal communication obstacles and arising problems, the necessity to develop communicative competence is emphasized.

The second part discusses the theoretical possibilities of learning to construcet the enabling relationship with family, by emphasizing the experiental learning process and peer communcation of the participants. This part provides models of experiential learning and professionalization, emphasizes the significance of social worker in consultat's role, specifies particularities of each professionalization stage which determines the quality of intercommunication and help (Bernar, 2002; Dreyfus, Dreyfus, 1980).

The third part of the paper analyzes the empirical professional identity formation assumpations by actualizing communcative competence development in the 
helping process for risk family. In this part the results of dissertation's qualitative research are provided (Eidukevičiūtè, 2013). The study was accomplished in accordance to hermaneutic perspective. 5 social workers working in non-governmental organizations which provide services of children day centres participated in the study. The study revealed the problems of communication between social worker and family as a client. Social worker with sufficient practical activity experience usually remains in the primary phase of help process - contact establishment. In one case family proactiveness is expected but it remains "invisible". Mother usually is communicated and the object of communication is child behaviour. Thus, based on the development of experiential learning model, it can be said that the research participant reflects the concept of the first - the newcomer professionalization stage. In the second case, the study reveals the assumptions for the concept of enabling the participants in social work with the family, based on a culture of dialogue. In this case, the family is "visible" as active and self-help in the process of dialogue partner. However, one can notice the lack of confidence in their employee competence. This suggests that the study participant reflects her experience. She needs expert practitioner or supervisor coaching, which would allow going to the second - the expertise professionalization stage of development.

While summarizing the paper provided results of analysis, the pertaining problems of practical social work knowledge development were emphasized when the activity is insufficiently considered, insufficiently reflected. While analyzing the individual process of experiential process the necessity of practitioner-expert or supervisor coaching in the experiential learning process by self-assessing and combining practical knowledge which were gained by acting in practice placement, theoretical knowledge and created professional knowledge. Such coaching enables to systematize elements recurring in situations, develop their professionality of social worker with the help of reflection. 